\title{
Humor Conversation Due to Violation of Cooperative and Politeness Principles
}

\author{
Masilva Raynox Mael \\ Universitas Negeri Surabaya \\ Indonesia \\ masilvamael@unesa.ac.id
}

\author{
Hespi Septiana \\ Universitas Negeri Surabaya \\ Indonesia \\ hespiseptiana@unesa.ac.id
}

\author{
Retnani \\ Universitas Negeri Surabaya \\ Indonesia \\ retnani@unesa.ac.id
}

\begin{abstract}
In a conversation, context determines the direction of the intended conversation. If one does not understand the context, the conversation will not be ideal. Uncertainty about context also can lead the conversation to a joke or humor, since there is a discrepancy with the intended context. This deviation in pragmatic can occur due to violation of cooperative principle contained in the realm of interpersonal roles, or can be through the maxim of correlation (relevance) or maxim of manner and politeness principle of the accompanying courtesy. This article discusses the daily conversations that occur among postgraduate students, as a source of data, and turned the conversation into a humorous conversation because of cooperative violations and politeness principles of fellow speakers.
\end{abstract}

Keywords-interpersonal role; cooperative principles, politeness principles

\section{INTRODUCTION}

Human cannot ignore the use of language in everyday life. Sutedi states that language is the medium used to convey ideas, desires, and wishes to others [1]. In addition, Chaer also states that language is a system of symbol, in a form of sound, arbitrary, productive and humane [2]. From both of the opinions it is true that language has a great influence on the conveyance of a person's ideas to be understood by his interlocutor. Therefore, sometimes when a person's language is not understood by the interlocutor, then the conversations are not meaningful.

In addition, in a conversation, context determines the direction of the intended conversation. If someone does not understand the context, then the conversation will not be ideal. Uncertainty about the context can also make the conversation a joke or humor, due to irregularities or inconsistencies with the intended context. This deviation in pragmatic language can occur due to violation of cooperative principles contained in the sphere of interpersonal role, through the maxim of relationship (relevance) or through the maxim of manner.

Another interpersonal role in a conversation that can result a joke can also occur in interpersonal rhetoric conversations, in conversations of irony, hyperbole and litotes. Conversations that occur seem to flow well because there is agreement of ideas or the suitability of the principle of cooperation between speakers and the interlocutor. But in contrast to this suitability, there is a kind of politeness violation of principles, which makes this conversation a joke.

Based on the aforementioned matters, this paper will deal with real-life experiences experienced by authors on the interpersonal role of conversations that leads to a joke or humor. The conversations occurred among fellow students of Postgraduate program of foreign languages of Universitas Negeri Surabaya, which occurs naturally and often leads to jokes. Although the students concentrate on foreign languages, but the conversations were in Indonesian language mixed with Javanese. This is because the students are Indonesians who are currently staying in East Java.

The discussion will include not only conversations that violate the principles of cooperation and their maxims, but also violations of the principles of politeness, and the relationship between the two principles. This discussion is expected to help people to understand the pragmatic elements in the language, and also can be used to strengthen their relationships after understanding the principles.

\section{THEORETICAL BASIS}

\section{A. The Interpersonal Role of Cooperative Principles}

The principle of cooperation is a part of the pragmatic discussion. In the interaction of communication, cooperation among the speakers and interlocutors are required so that communication can run smoothly. From this cooperation factor, an appropriate speech interaction will be created, because between speakers and the interlocutor a continuity of speech or idea will be established. Cooperation is a simple form in which people who are engaged in speech acts generally do not attempt to confuse, play, or hide information between one another. In many conversations, cooperation is the starting point for explaining what is being said [3]. This cooperation is based on a background of knowledge (perception), referents, context and the same purpose. 
Therefore, the principles of cooperation play an important role in reaching a meeting point in a conversation. If there is a breach of the principle of cooperation, then the delivery of ideas in a conversation cannot run properly. It can even cause problems. Breach of principle of cooperation can also make a conversation a joke. This discussion will put forward a conversation of violations of a principle of cooperation that results in a joke or humor.

\section{B. The Interpersonal Role of the Principle of Politeness}

Politeness is generally related to the relationship between two participants who can be called 'self' and 'other'. The principle of politeness in pragmatic studies is outlined by some experts. Among them are Leech, Robin Lakoff, Bowl and Levinson. The principle of politeness relates to two participants of the conversation, namely self and other. The self is the speaker, and the other is the interlocutor. The principle of politeness in conversation comes from several factors. These factors occur due to the degree of status, social values in society as well as age and power. In addition, kinship factors can also affect the principle of politeness [3]. Therefore, one should pay attention to this principle when he/she will start a conversation with others, so that the intent or idea is conveyed correctly.

Violations of the principle of politeness often occur in humorous conversations. This is due to different factors that affect this principle of politeness. In this discussion, we will examine how violations of the principle of politeness that leads to jokes in the conversation.

\section{METHOD}

This research is a qualitative research with documentation method. Data was taken from documentation of conversation between postgraduate students who were recorded and analyzed in accordance with existing theories.

\section{DISCUSSION}

\section{A. The Violation of Cooperative and Politeness Principles}

Violations of cooperative principles may occur due to either deliberate or accidental elements. Leech says that humans need the cooperative principles to explain the relationship between meaning and power more easily [4]. This means the relationship in the conversation becomes very important, resulting in compatibility. The deliberate violation of the cooperative principles could be to bring a joke in a conversation. This deliberate one can be done if the speakers and the interlocutors have a good familiarity. In other words, the principle of politeness is ignored in the case of this conversation.

For more details, let's consider its application in the following conversation quote.

\section{Data 1}

Context: This conversation occurred in a postgraduate student's home when she held a party. When it was time for Friday prayers, A asks B where to pray.

Quote:
A: Where will we have the Friday prayer?

B: Come on, A. A postgraduate student asks where to pray Friday?! That's absolutely in a mosque.

Friends: (laugh)

From the above conversations, there was a violation of the cooperative principle, in this case the maxim of manner and relationship (relevance). Actually, what speaker A meant was ' where is the nearest mosque to perform Friday prayers'. Choosing the sentence in a form of a question can be rhetorical because, in general, everyone performing the Friday prayers must be in a mosque. B actually got speaker A's intention, because she actually understood the context. However, B violated the cooperative principle, as if she did not understand speaker A's intentions. Because of the violation of this cooperative principle, this conversation becomes a joke or humor.

Such conversation will not be acceptable if there is no intimacy between the speakers and his or her interlocutor. In the absence of intimacy or not knowing each other, this conversation can cause problems. The reason is it violates the principle of politeness. But from another point of view, if the speaker with the other person has known each other, it is precisely that this humorous conversation will make them more intimate.

\section{Data 2}

Context: Conversation between C and D. The conversation occurred on the way home after ordering some boxes of rice for Sunday activities. D ordered rice with fried chicken. But there was a special box that $\mathrm{D}$ ordered, to have the fried chicken replaced with beef.

\section{Quote:}

C: Why did you order a special box to have beef instead of fried chicken?

D: Oh ..., that's for one of my students. He cannot eat twolegged animal meat. He said, "Allergies".

C: Oh ..., you have to be careful. You should confirm the sales person.

D: Why?

C: What if it was a defective cow that has only two legs, then your student cannot eat it, right. Pity your student. It's useless then to have a special order, moreover.

D: (laugh) ... That's right. I didn't know you were so clever.

C: Of course, I am. Indeed, we would not know if the cow is defective, having only two legs.

From the above conversations, it can be seen that this conversation was a violation of the cooperative principle. Speaker $\mathrm{C}$ was actually trying to implement cooperation by giving warning to D. But this was a rhetorical warning, because actually the intentions that $\mathrm{D}$ conveyed about the twolegged animals were poultry. One of D's students cannot eat poultry. The choice of two-legged words spoken by $\mathrm{D}$ can bring up a humorous conversation. Actually $\mathrm{C}$ understood the purpose of $\mathrm{D}$, but $\mathrm{C}$ violates the cooperative principle to create a joke.

As presented in data 1 , this style of conversation cannot be applied if there is no intimacy between the speaker and the 
interlocutor. If they are not intimate, it will most likely be a problem due to violating the principle of politeness, and jokes. On the other hand, this style of conversation can also be a way to know better and get closer with friends. Indeed, such violent in politeness principles are widely used to make jokes or humor conversations.

\section{Data 3}

Context: This conversation occurred in a class. E, F and $\mathrm{G}$ were talking about $\mathrm{H}$ and I who were waving their hands to them from the school canteen. The canteen is across the classroom.

\section{Quote:}

E: Look! H and I are waving hands.

F: Yes, Let them be. We do not need to wave back. They must think we are in a zoo.

G: (while waving hands to $\mathrm{H}$ and $\mathrm{I}$ ) Well, that is okay.

They consider us as if we were in a zoo, then we consider them as in safari park.

F: (laugh out loud). Oh, Please....

From the above conversations, it can be seen that a violation of politeness principles occurred. F thought that he was being insulted because he was regarded as an animal in a zoo by the waves of $\mathrm{H}$ and I who were younger than him. The class was considered a cage while the $\mathrm{H}$ and $\mathrm{I}$ in the canteen were considered like zoo visitors waving their hands. However, $G$ diluted the atmosphere by applying the cooperative and politeness principles by keep waving hands to $\mathrm{H}$ and I. G said that if they consider them as animals in a zoo, they were no more than being in Safari Park. If the place was assumed as Safari Park, then the class was considered as a car while those in the outside (the canteen) were as animals.

F, who felt humiliated, laughed at G's joke. This conversation style protected the principle of politeness with the cooperative principle. Cooperation that $\mathrm{G}$ did with jokes made it seemed like the politeness principle was protected. The violation of the politeness principle seemed lost due to this joke.

\section{CONCLUSION}

Based on the conversation examples, the paper concludes that

1. Violations of the cooperative and politeness principles to the maxims can lead a conversation to a joke.

2. A humor conversation cannot work properly or can even cause problems if there is no intimacy between the speaker and the interlocutor.

3. Humor conversation can build more intimate relationship between people.

4. The cooperative principle can protect the politeness principle with a humorous conversation style.

\section{REFERENCES}

[1] D. Sutedi. "Dasar-dasar Linguistik Bahasa Jepang", Bandung;

Humaniora Utama Press. 2011.
[2] A. Chaer And L. Agustina. "Sosiolinguistik. Perkenalan Awal", Jakarta: Rineka Cipta, 1995.

[3] G. Leech. "Prinsip-prinsip Pragmatik diterjemahkan oleh MDD Oka dan Setyadi Setyapranata", Jakarta: Universitas Indonesia Press, 1993.

[4] G. Yule. "Pragmatik", Yogyakarta; Puestaka Pelajar, 2006. 